\title{
The Effect of Pharmaceutical Patent Term Length on Research and Development and Drug Expenditures in Canada
}

\author{
Leffet de la durée des brevets \\ pharmaceutiques sur les dépenses \\ en R\&D et en médicaments au Canada
}

\author{
政 \\ by PAUL GROOTENDORST \\ Faculty of Pharmacy, University of Toronto \\ Toronto, ON \\ LIVIO DI MATTEO \\ Department of Economics, Lakehead University \\ Thunder Bay, ON
}

\begin{abstract}
While pharmaceutical patent terms have increased in Canada, increases in patented drug spending have been mitigated by price controls and retrenchment of public prescription drug subsidy programs. We estimate the net effects of these offsetting policies on domestic pharmaceutical $R \& D$ expenditures and also provide an upper-bound estimate on the effects of these policies on Canadian pharmaceutical spending over the period 1988-2002. We estimate that R\&D spending increased by $\$ 4.4$ billion (1997
\end{abstract}


dollars). Drug spending increased by $\$ 3.9$ billion at most and, quite likely, by much less. Cutbacks to public drug subsidies and the introduction of price controls likely mitigated drug spending growth. In cost-benefit terms, we suspect that the patent extension policies have been beneficial to Canada.

\section{Résumé}

Même si la durée des brevets a augmenté au Canada, les augmentations dans les dépenses en médicaments brevetés ont été atténuées par les contrôles des prix et l'annulation de programmes de subventions pour médicaments sur ordonnance. Nous estimons les effets nets de ces politiques compensatoires sur les dépenses en R\&D dans le domaine pharmaceutique à l'échelle nationale et fournissons également une estimation de la limite supérieure des effets de ces politiques sur les dépenses en médicaments de 1988 à 2002. Nous estimons que les dépenses en R\&D ont augmenté de 4,4 G\$ (dollars de 1997). Les dépenses en médicaments ont augmenté de 3,9 G\$ au plus et, fort probablement, de beaucoup moins. Les réductions des subventions publiques aux programmes d'assurance-médicaments et, possiblement, l'introduction de contrôles des prix ont probablement réfréné les augmentations des dépenses en médicaments. Sur le plan des coûts-avantages, nous avons l'impression que les politiques sur la prolongation des brevets ont été bénéfiques pour le Canada.

\section{$\overbrace{\text { he last two decades have Seen Several countries extend drug }}$ patent terms - the period of market exclusivity afforded to new pharmaceu- tical drugs - so as to conform to the Trade-Related Aspects of Intellectual} Property Rights (TRIPS) and other international trade agreements. Indeed, Canada extended drug patent terms in 1987 (as part of the US-Canada Free Trade Agreement), in 1993 (as part of the North American Free Trade Agreement) and again in 2001 (as part of TRIPS). Was this a good policy for Canada? The answer depends on the value to Canada of these trade agreements, an issue discussed by Britton (1998), Mehanna and Shamsub (2002) and Singh (2002). The answer also depends on the value of longer patent terms per se. The standard rationale for lengthened patent terms is to postpone competition from "generic" firms, thereby allowing incumbent firms to charge higher prices for a longer period of time and collect additional profits with which to recoup the costs of research and development (R\&D). Longer patent terms should therefore be judged on the value of the innovation generated by the attendant increase in $R \& D$.

The value of longer drug patent terms is the value of the increase in the length and health-related quality of life due to new drugs that would have been delayed, or 
not introduced at all, had patent terms not been extended. Offsetting this benefit is the cost of higher drug prices. From an economic perspective, the additional drug expenditures due to longer patent terms is not a cost - it is merely a transfer from drug payers to drug patent holders to support R\&D. The primary economic cost of higher drug prices is the value of health not realized due to the reduced consumption of drugs attributable to higher drug prices. The patents policy is economically desirable if the benefits exceed the costs.

In this paper, we investigate aspects of the benefits and costs of longer drug patent terms in Canada. We do so by estimating the effects of the patent policy changes on drug spending, drug prices and drug R\&D in Canada. We also investigate how expenditure control policies introduced by the federal government (in the form of direct drug price controls) and provincial government drug plans (in the form of subsidy cutbacks) after 1987 may have mitigated the effects of higher drug prices.

We were unable to conduct a comprehensive assessment of the value of the patents policies. Such an assessment would require the valuation of the drugs that have been developed on account of these policies. This would be difficult to do for several reasons. First, drug development is a lengthy process, and the health impacts of the new drugs developed owing to the patent term extensions are likely only now being realized. Second, most patent-holding drug firms operating in Canada are multinationals who have discretion over the location of $\mathrm{R} \& \mathrm{D}$. One would therefore need to assess the impact on global $R \& D$ and drug innovation of the domestic patent act extension. Third, one would need to assess the health impact of these new drugs, which is no trivial undertaking.

Instead of assessing the health "output" of pharmaceutical R $\& D$, we focus on the "inputs" in the drug development process - Canadian pharmaceutical R\&D expenditures. We assess the change in such expenditure before and after the introduction of the 1987 patent term extension. The corresponding change in motor vehicle sector $\mathrm{R} \& \mathrm{D}$ expenditure is used to control for growing domestic $\mathrm{R} \& \mathrm{D}$ tax credits and other factors that could have independently increased $R \& D$. We verify these estimates using an independent source of data on domestic pharmaceutical $R \& D$. We also speculate on the economic value of this increase in $\mathrm{R} \& \mathrm{D}$ expenditure.

Further, we estimate the amount of money transferred from drug payers to drug firms on account of the patent term extension. We do so by examining rates of growth in adjusted per capita prescription drug costs over time. We use regression methods to adjust per capita drug spending for demographic composition, income, provincial drug plan cost controls and other factors that may have changed over our sample period, 1976-2002. We then examine the adjusted per capita drug cost series for any pronounced increases after patent terms were extended. This method is admittedly imprecise because we cannot control for the single largest determinant of recent drug cost growth: the substitution of relatively costly new drugs for older drugs (Morgan 
2001). Any observed increases in adjusted drug costs therefore could be due to both "patent extension" - higher drug prices of existing patented drugs - and replacement of older drugs by newer drugs (some of which may have been introduced on account of the patent extension). Faced with this identification problem, the best we can do is to estimate an upper bound on the effect of patent extension on drug costs - the effect that would exist if there were no drug substitution-induced increases in drug costs.

The regression models estimated to adjust drug spending, described above, provide estimates of the impact of provincial government drug cost controls on total drug spending. To gain insight into the effect of federal drug price regulation on drug expenditure, as distinct from the changes in drug plan subsidies and patent term extension, we also analyze time trends in drug price indices and per capita drug expenditures in Canada and the United States, which has not experienced federal price regulation nor recently lengthened patent terms.

Briefly, we find strong evidence that domestic pharmaceutical R\&D increased after 1987. We estimate the increase at about Cdn $\$ 4.4$ billion (1997 dollars). We find little evidence of increased drug expenditures immediately after drug patent terms were extended in 1987; this finding is likely due to the retrenchment of public sector drug insurance plans and the introduction of price regulation of patented drugs. We do find a marked increase in drug expenditures after 1996, which we estimate at Cdn $\$ 3.9$ billion (1997 dollars). While this increase is consistent with a delayed response to the patent term extension, similar increases were also observed in the United States, suggesting that other factors, such as the introduction of new drugs, may have been primarily responsible.

\section{A Brief History of Canadian Drug Patent Policy}

Concerns over high drug prices and low levels of $R \& D$ by patent-holding multinational pharmaceutical drug manufacturers led the Canadian federal government in 1969 to modify the "compulsory licensing" provisions of the Patent Act. Generic drug firms were permitted to import and sell patented drugs in exchange for payment of $4 \%$ of sales to the patent holder. The 29 patented drugs marketed during the period 1969-1984 that faced generic competition received an average of 7.6 years of market exclusivity (Canada 1985). However, during the last three years of the compulsory licensing regime (1985 to November 1987), periods of market exclusivity for some popular drugs, such as the ulcer drug cimetidine, were as low as four years. Pressure applied during trade negotiations and promises by patent-holding firms to increase domestic R\&D led to the weakening in December 1987 and elimination in March 1993 of compulsory licensing, under the auspices of bills C-22 and C-91, respectively. ${ }^{1}$ Bill C-22 guaranteed patentee firms seven years of market exclusivity (10 years if generic firms imported active ingredients) after receiving federal approval, known as 
"Notice of Compliance" (NOC), to market the drug. Bill C-91 eliminated compulsory licensing and provided 20-year patent terms from the date of patent filing. According to industry sources, it takes about 10 years for a drug to receive a patent, and then undergo testing and receive an NOC, so effective patent terms are about 10 years. Bill C-91 also provided patentee firms the right to delay the market introduction of generic drugs by up to 24 months by claiming patent infringement. ${ }^{2}$ Furthermore, the onset of Bill S-17 in July 2001 extended patent protection to 20 years from the date of patent filing for non-expired drug patents issued before 1989, when they lasted only 17 years from time of patent grant. These legislative changes have brought Canadian patent policy into conformity with the TRIPS agreement.

Several government policies initiated in the late 1980s may have mitigated the profits flowing to patentees (Vandergrift and Kanavos 1997; Anis 2000). First, as part of Bill C-22, in 1988 the federal government created the Patented Medicine Prices Review Board (PMPRB), a quasi-judicial agency charged with regulating the introductory prices and increases of drugs. Bill C-91 strengthened the enforcement powers of the PMPRB by enabling it to fine and order price rollbacks on non-compliant firms. Second, the provincial government prescription drug subsidy programs ${ }^{3}$ began to reduce subsidy levels via beneficiary co-payments, prescribing restrictions and other cost control measures (Grootendorst 2002). If the drug use of public drug plan beneficiaries is not price sensitive, public drug expenditures were simply shifted to the private sector in the form of higher direct patient expenditure and expenditures on private drug insurance plans, leaving patentee profits largely unaffected. Conversely, if drug use is price sensitive, the retrenchment of provincial drug subsidies has likely reduced industry profits.

\section{Empirical Methodology}

\section{Pharmaceutical drug R $\& D$}

We estimated the effect of patent protection on pharmaceutical R\&D, as measured by the level of expenditure on Canadian pharmaceutical R $\& D$. These include outlays on basic research (identifying new therapies), applied research (establishing that such therapies are safe and efficacious, according to standards of evidence set by federal regulators, as well as research into manufacturing processes) and "other qualifying" research (drug regulation submissions, bioavailability studies and post-marketing drug safety/effectiveness studies). Data assembled by the PMPRB indicate that over the period 1988-2002, about 20\% of total pharmaceutical R\&D expenditures conducted by firms selling patented drugs were allocated to basic research, and $60 \%$ to applied research (PMPRB 2004). 
There is anecdotal evidence that some of the post $-1987 \mathrm{R} \& \mathrm{D}$ expenditure increase in Canada is due to the negotiations that resulted in the extension of patent terms. With the passage of Bill C-22, the domestic patent-holding pharmaceutical industry association promised to increase its annual $\mathrm{R} \& \mathrm{D}$ expenditure as a percentage of sales from under $6 \%$ in 1987 to $10 \%$ by 1996 . With the elimination of compulsory licensing in 1993, the association affirmed this commitment into future years and promised both an additional \$200 million in support for biomedical research and training in academic institutions across Canada over five years (1993-1998) as well as an additional $\$ 400$ million in unspecified new investments by the end of 1996 (Industry Canada 1997). While some of the R\&D increase is undoubtedly due to changes to the Patent Act, these may not be the sole contributing factor. In particular, the growth in federal and provincial tax credits for domestic R\&D might have independently increased pharmaceutical R\&D expenditure (Iqbal 1995; Pazderka 1999; Dahlby 2005; MacKenzie 2005).

We had access to data on annual domestic pharmaceutical R\&D expenditures from both the PMPRB and Statistics Canada. Under the terms of Bill C-22, firms selling patented drugs in Canada must report on their R\&D activity to the PMPRB. Research and development activity is defined as those expenditures eligible for an Investment Tax Credit for scientific research and experimental development under the provisions of the Income Tax Act in effect on December 1, 1987. These data are limited in that the $\mathrm{R} \& \mathrm{D}$ activity for those firms that developed but did not sell drugs in Canada is excluded; moreover, these data cover just the post-policy period, 19882002. The Statistics Canada data are available for a longer period of time (19722002) and include R\&D activities of all firms, irrespective of their patent-holding status, in the "pharmaceutical and medicine" and other industrial subsectors. These data include all R\&D expenditure (such as capital purchases including land, buildings and equipment), exclude expenditures related to drug marketing and promotion, and are defined according to the tax legislation in effect in the reporting year. Data are collected from a combination of direct surveys and administrative data required of firms claiming R\&D tax credits.

The impact of patent term extension policies on pharmaceutical $R \& D$ is defined as the difference between what $R \& D$ would have been had patent terms not been extended and actual R\&D expenditures (with patent terms extended). To estimate the former, in the first instance we extrapolated trends in pharmaceutical R\&D expenditures (using the Statistics Canada data) from before the introduction of Bill C-22 in 1987 to the period when the policy was in place (after 1987). The slope and position of the baseline trends were estimated by linear regression. This approach assumes that all post-1987 R\&D growth above the pre-1987 trend line is due to the patent policies. Next, we relaxed this assumption. We subtracted from the pre-post 1987 change in pharmaceutical R\&D estimated above the component that would have occurred even 
without the patent changes. This latter component was proxied by the pre-post 1987 change in motor vehicle sector R\&D. Like the pharmaceutical sector, the motor vehicle sector is capital- and research-intensive; has long product development cycles; is characterized by a high degree of foreign ownership; and could have responded to increasingly lucrative federal $R \& D$ tax subsidies by shifting the location of their $R \& D$ to Canada.

Finally, we estimated the patent-induced increase in pharmaceutical $R \& D$ using the PMPRB data to ensure that the estimates from the Statistics Canada data were reasonably robust to the definition of $R \& D$-eligible expenditures and the set of pharmaceutical firms sampled. Using the PMPRB data, we estimated the effect of postBill C-22 patent extension as any growth of the pharmaceutical R\&D expendituresto-sales ratio in excess of 6\%, the ratio that prevailed in 1987. From the Statistics Canada data, it appears that this ratio was relatively stable prior to 1987, making this a sensible identification strategy.

\section{Prescription drug spending}

To estimate the effects of both the Patent Act amendments and the countervailing reductions in public drug subsidies on pharmaceutical sector revenues, we constructed regression models of provincial total retail prescription drug expenditures as a function of year and region dummies and lagged public drug expenditures, while controlling for other variables that could affect drug spending. The coefficients on the year dummies allow us to assess whether there was a marked increase in drug spending after the introduction of the Patent Act changes. We recognize that our estimate might be confounded by other factors that might increase drug costs over time, in particular, the introduction of new drugs (Morgan 2001). The year effects therefore likely identify the maximum possible impact of patent extension on drug expenditures and allow us to make an upper-bound estimate. Region dummies were included in the model to capture time-invariant regional differences in provincial drug plan generosity. Lagged real public drug expenditure was included to control for changes in provincial drug plan generosity. The idea here is that if public drug plan beneficiaries are price sensitive, then reductions in public drug expenditure should be only partially offset by increased private (out-of-pocket) spending, thereby reducing total drug expenditures.

We also controlled for real per capita GDP, its square and the proportion of the population in various age groups (18-44, 45-64, 65-74, 75 years and older), as well as the squares of these variables, ${ }^{4}$ since the medical need for drugs varies systematically through the life cycle. The per capita number of physicians, both primary care and specialists, who likely prescribe to outpatients, as well as the square of this variable, were included to control for changes in prescriber availability. In addition, the de-institutionalization of hospital patients in Canada during the 1990s shifted the location of drug use from inpatient to outpatient settings (Tully and Saint-Pierre 1997). A 
hospital share of total healthcare expenditures variable and its square were included to control for the attendant impact on outpatient drug expenditures.

Retail drug expenditures information is produced by IMS Health Canada. These data are dollar-value estimates (excluding dispensing fees but including wholesale markups) and unit volumes of pharmaceutical products purchased by Canadian retail pharmacies. Data from purchase invoices are collected monthly from a representative sample of 210 retail pharmacies, stratified by region, store size (large or small) and type (independent vs. chain). The sample data are then projected to the universe of Canadian drugstores. Data were provided annually over the period 1976-2002 for the provinces of British Columbia, Alberta, Ontario, Quebec, the Prairie region (comprising the provinces of Saskatchewan and Manitoba) and the Atlantic region (New Brunswick, Nova Scotia, Prince Edward Island and Newfoundland and Labrador). As our focus is on pharmaceutical manufacturers' revenues, we subtracted expenditures on drug distribution. Data compiled by industry sources suggest that wholesale markups are roughly $5 \%$ of factory gate drug expenditures, and therefore, these drug expenditures were divided by 1.05 .

Data on provincial government drug plan and other public drug expenditures aggregated by province and year over the period 1975-2002 were obtained from public accounts records and assembled by the Canadian Institute for Health Information (CIHI). Like the IMS data, the CIHI public drug expenditures data exclude hospital use, but include dispensing fees and wholesale markups. Based on statistics from the Ontario government drug subsidy program, retail and wholesale markups account for about $18 \%$ of program expenditures, so public drug expenditures were then divided by 1.18 to reflect payments made to drug manufacturers. The data used to construct other variables came from a variety of sources. Data on population counts (by age and sex, GDP and expenditure deflators) were obtained from Statistics Canada CANSIM II. Data on physician counts and total healthcare spending by expenditure category were obtained from CIHI. Further details on these and other data are available in the Appendix (http://www.longwoods.com/product.php?productid=18677).

\section{Source of drug spending growth}

Because the Patent Act amendments resulted in both longer periods of market exclusivity for patented drugs and the introduction of patented drug price regulation, we were unable to identify their separate effects on domestic drug expenditures. To shed light on the sources of drug expenditure growth, we analyzed growth in various drug price indices before and after the onset of the patent changes in 1987. Changes in a drug price index will reflect the effects of federal regulation of rates of price inflation of existing patented drugs, but will not reflect the effect of price regulation on introductory prices of new drugs; they also are unlikely to capture the effect of delayed 
generic competition on drug prices. The reason is that all new drugs, irrespective of their therapeutic substitutability for existing drugs, count as distinct products in the index. The index will therefore not register the price drop when generics are substituted for brand-name drugs, nor will it register the price increase when new patented drugs are substituted for older drugs (Griliches and Cockburn 1995).

We had access to the patented medicines price index (PMPI), a measure of the ex-factory prices of patented drug products sold in Canada constructed by the PMPRB, but these data are available for the post-Bill C-22 period only (19882002). We instead focused on growth in the ex-factory prices of all drugs sold in Canada (irrespective of patent status) using the pharmaceuticals component of the Statistics Canada Industrial Product Price Index (IPPI) over the period 1981-2002. As patented medicines account for over two-thirds of total prescription drug expenditures (PMPRB 2004), this index should capture variation in patented drug prices. Moreover, there is evidence that some manufacturers raised off-patent brand drug prices in order to mitigate the effects of patented drug price regulation (Anis and Wen 1998), so an index that captures price change in both patented and non-patented drugs is preferable. Growth in the price indices was expressed in real terms by subtracting growth in the national all-item CPI.

We also compared Canadian drug price inflation and per capita drug expenditure growth to inflation and expenditure growth observed in the United States in order to control for factors that could have independently affected North American trends in drug spending. Given that the United States, like Canada, has a mixed public-private system of drug finance, but has not introduced drug price regulation or recently lengthened patent terms, the comparison serves as a useful benchmark for evaluating Canadian policy changes.

The parameters of all regression models were estimated using ordinary least squares (OLS). The presence of non-spherical disturbances, however, renders the OLS estimates of the standard errors inconsistent. We therefore used the Newey-West heteroscedasticity and autocorrelation consistent covariance matrix estimator (Newey and West 1987) to ensure that hypothesis testing was valid in the presence of up to twoyear autocorrelation. The regression equations and specifications used are described briefly in Appendix II (http://www.longwoods.com/product.php?productid=18677).

\section{Results}

\section{Pharmaceutical drug R\&D}

We first describe time trends in pharmaceutical $R \& D$ activity, expressed as a share of total industrial $R \& D$ (Figure 1), and in relation to total sales revenue (Figure 2) along with comparative data from the total industrial, total manufacturing, and motor vehicle 
FIGURE 1. Pharmaceutical and medicine sector share of total industrial R\&D expenditures, Canada, 1972-2002

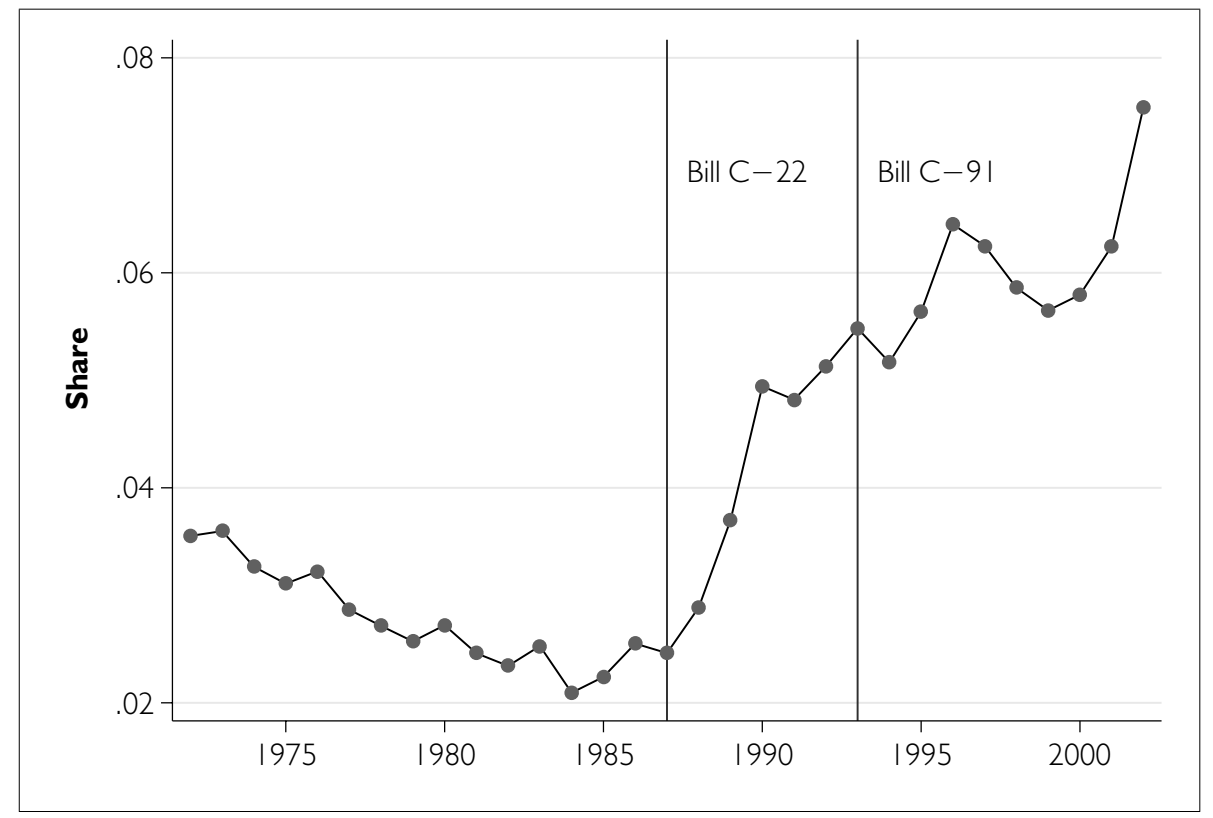

Source: Statistics Canada.

FIGURE 2. Ratio of R\&D expenditures to sales revenue by sector, Canada, 1975-2001

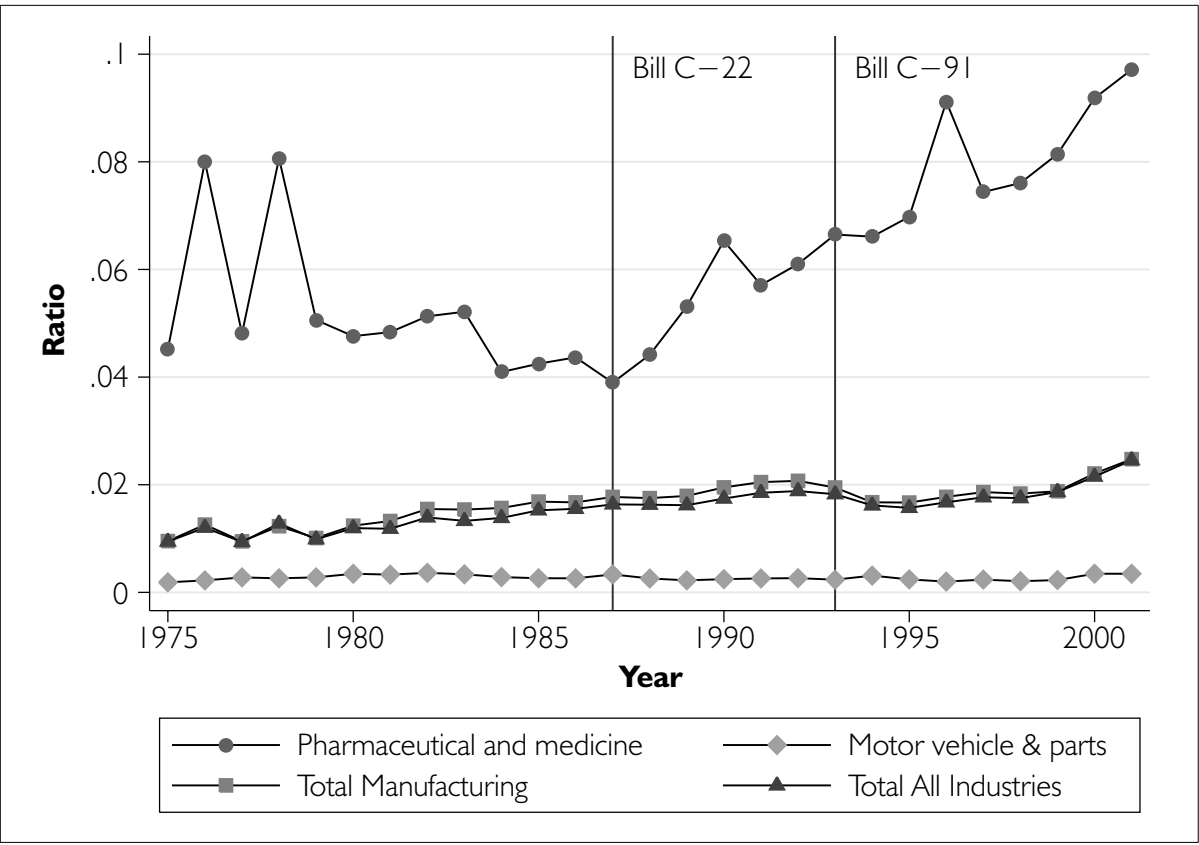

Note: The two outlier observations on pharmaceutical R\&D to sales, in 1976 and 1978 , arise owing to particularly low sales revenue estimates for those years. 
and parts sectors. Pharmaceutical R\&D expenditures increased substantially after 1987, both in relation to $R \& D$ conducted in other industrial sectors and also relative to pharmaceutical sales. In order to estimate the magnitude of the $R \& D$ expenditure increase, we initially assumed that all post-1987 R\&D growth was due to patent term extension and that the pre-Bill C-22 linear trend in R\&D spending would have continued into the future, had the patents policy not been modified. We estimate that the changes to the Patent Act increased real pharmaceutical R\&D spending by $\$ 4.6$ billion over the 15-year period 1988-2002 (with a 95\% confidence interval of \$4.1-\$5.1 billion).

We next re-estimated the increase in pharmaceutical $R \& D$ expenditures, this time relaxing the assumption that all post $-1987 \mathrm{R} \& \mathrm{D}$ growth was due to patent term extension. Our identifying assumption is that $\mathrm{R} \& \mathrm{D}$ expenditure growth in the motor vehicle and parts sector mimics what pharmaceutical $R \& D$ would have been had patent terms not been modified. As Figure 3 indicates, prior to the introduction of Bill $\mathrm{C}-22$, this comparator had $\mathrm{R} \& \mathrm{D}$ expenditure levels that were very similar to those in the pharmaceutical sector. We estimate that patent term extension increased real pharmaceutical R\&D spending by $\$ 4.4$ billion over the 15 year period 1988-2002 (with a $95 \%$ confidence interval of $\$ 3.8-\$ 5.0$ billion). This estimate is $\$ 200$ million lower than the previous estimate, implying that pharmaceutical sector R\&D has increased

FIGURE 3. Nominal R\&D expenditure in pharmaceutical and medicine vs. motor vehicle and parts sectors, Canada, 1972-2002

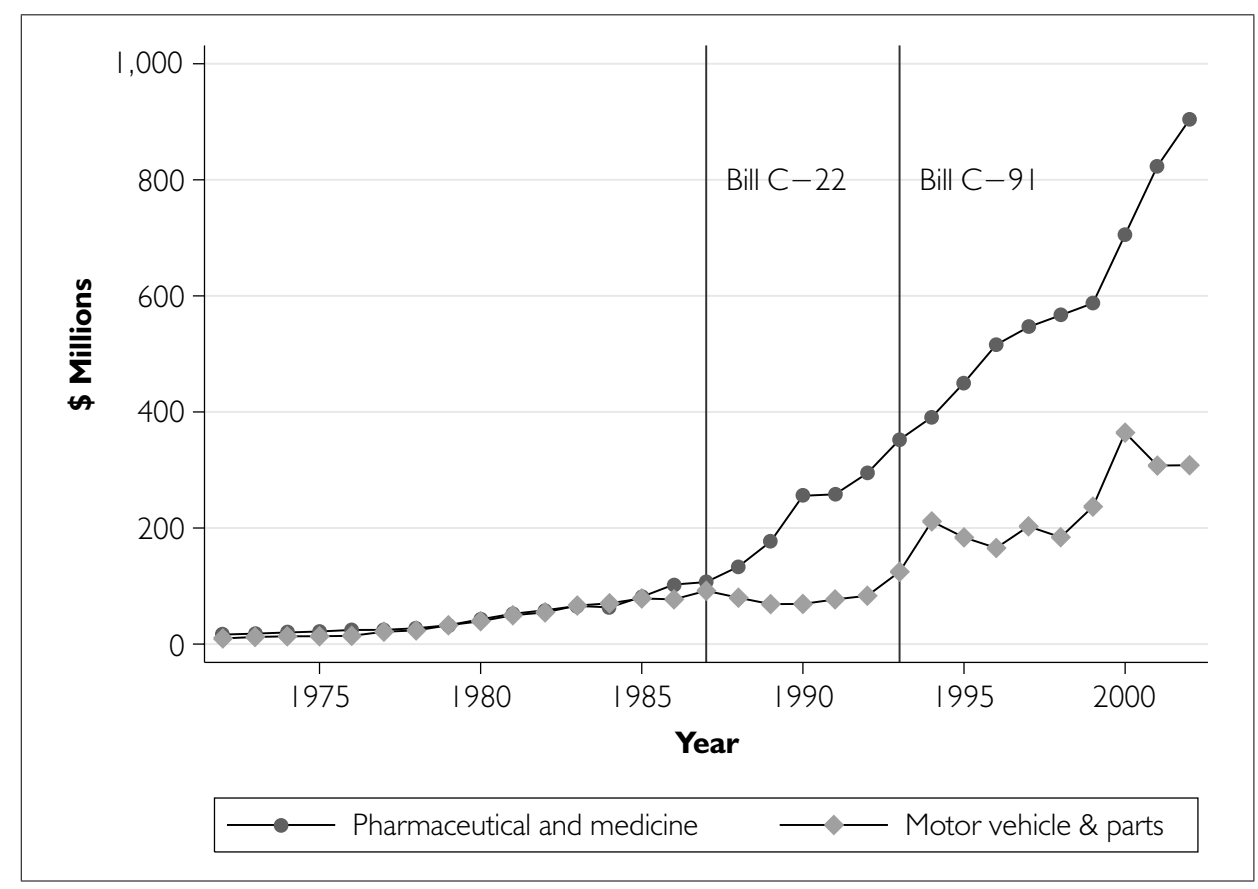


by $\$ 200$ million over and above its pre-Bill C-22 trend during 1988-2002 for reasons other than patent term extension.

Finally, to ensure that our results were robust to the choice of $R \& D$ data used, we re-estimated the patent-induced increase in pharmaceutical R\&D using the PMPRB data, albeit with the identifying assumption that the ratio of $R \& D$ to sales observed in the year before the introduction of Bill C-22 (6\%) would have remained fixed into the future. We estimate that the patent extensions increased real pharmaceutical $R \& D$ spending by about $\$ 4$ billion over the period 1988-2002. This estimate is in line with the estimates produced using the Statistics Canada data.

\section{Prescription drug spending}

We inspected trends in annual growth of real per capita retail prescription drug expenditures since 1976. The total expenditures growth data ("total" in Figure 4) suggest that while real outpatient drug expenditures increased by over $\$ 250$ per person during the period 1976-2002, there does not appear to have been a particularly rapid increase in drug expenditures after the extension of patent terms in 1987. Indeed, after 1988 expenditures grew less rapidly and stabilized after the introduction of Bill C-91 in 1993. After 1996, however, total expenditures increased sharply. Based on this unconditional analysis, the combination of patent term extension and direct price regulation introduced in 1987 has at most resulted in a delayed increase in drug costs. Figure 4 also displays growth in public sector drug expenditures. The distance between the total and public curves, representing private drug expenditure growth, is negligible until the mid-1980s. Thereafter, during the era of retrenchment of the public sector drug plans, private expenditure costs increased substantially; by 2002, cumulative private cost growth had almost caught up to the cumulative growth in public costs.

We next estimated regression models in order to assess whether the pattern of total drug expenditure growth observed in the unconditional analyses remained after conditioning on lagged public prescription drug spending and other covariates. The estimates indicate substantial regional variation in real per capita retail drug expenditure, with spending highest in the province of Quebec and lowest in the Prairie region. Drug expenditures increase with the fraction of the population in older age groups, peaking with age $75+$, but the relationship is not monotonic: the estimates suggest dips in per capita expenditure at 18-44 years and 65-74 years. The relationship between the density of prescribing physicians and real per capita drug expenditure follows an inverted U-shape pattern, with a maximum at 1.4 physicians per 1,000 population. This relationship is consistent with the hypothesis that at low levels of physician density, increases in density facilitate patient access to prescribers, thereby increasing medication use. Continued increases in density free physicians' available time per patient to the point where physician time replaces medication prescribing. 
Real per capita GDP and the hospital share of total healthcare spending also follow an inverted $U$-shape relationship with per capita drug expenditure, with maxima at $\$ 31,600$ and 0.40 , respectively. The coefficient on lagged real per capita public drug expenditures is 0.54 . Converting this figure into an elasticity, and evaluating it at the sample means, suggests that a $1 \%$ decrease in public drug expenditures will reduce total drug expenditures in the next period by $0.27 \%$ ( $95 \%$ confidence interval: $0.20 \%-$ $0.35 \%)$. The retrenchment in public sector drug subsidies has therefore modestly reduced drug expenditures.

FIGURE 4. Growth in real per capita retail prescription drug expenditures since 1976, total and publicly funded component, with $95 \%$ confidence intervals

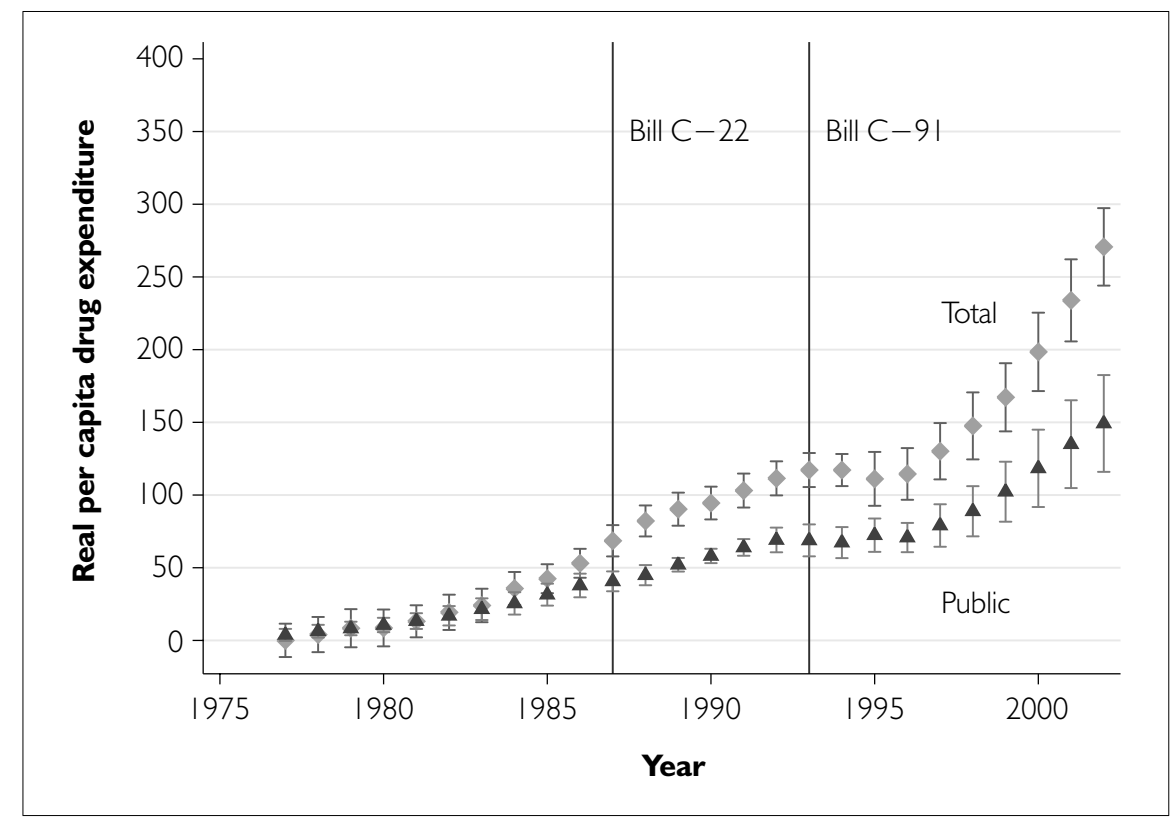

Note: The first vertical line indicates the implementation of Bill C-22 in December 1987;
the second vertical line indicates the introduction of Bill C-9I in March 1993.
Sources: IMS Health Canada; Canadian Institute for Health Information.

Turning next to the year-effects estimates, the sharp increase in drug expenditures after 1996 observed earlier is still apparent in the conditional analyses (Figure 5), suggesting that this increase is not entirely a result of changes in real per capita GDP or other time-varying covariates. Proceeding on the assumption that the increase represents a delayed response to the lengthened patent terms, we estimated the incremental per capita drug costs as the difference in the growth in drug costs between 1996 and 
2002 less the growth in drug costs during the equal-length period immediately prior to the introduction of Bill C-22, 1981-1987. Incremental per capita drug costs were converted into national figures by multiplying by the average provincial population of Canada over the period 1996-2002. This calculation yielded an estimate of $\$ 3.92$ billion, with a $95 \%$ confidence interval range of $\$ 2.97-\$ 4.87$ billion.

FIGURE 5. Growth in real per capita total retail prescription drug expenditures since 1976, adjusted for changes in time-varying covariates, with $95 \%$ confidence intervals

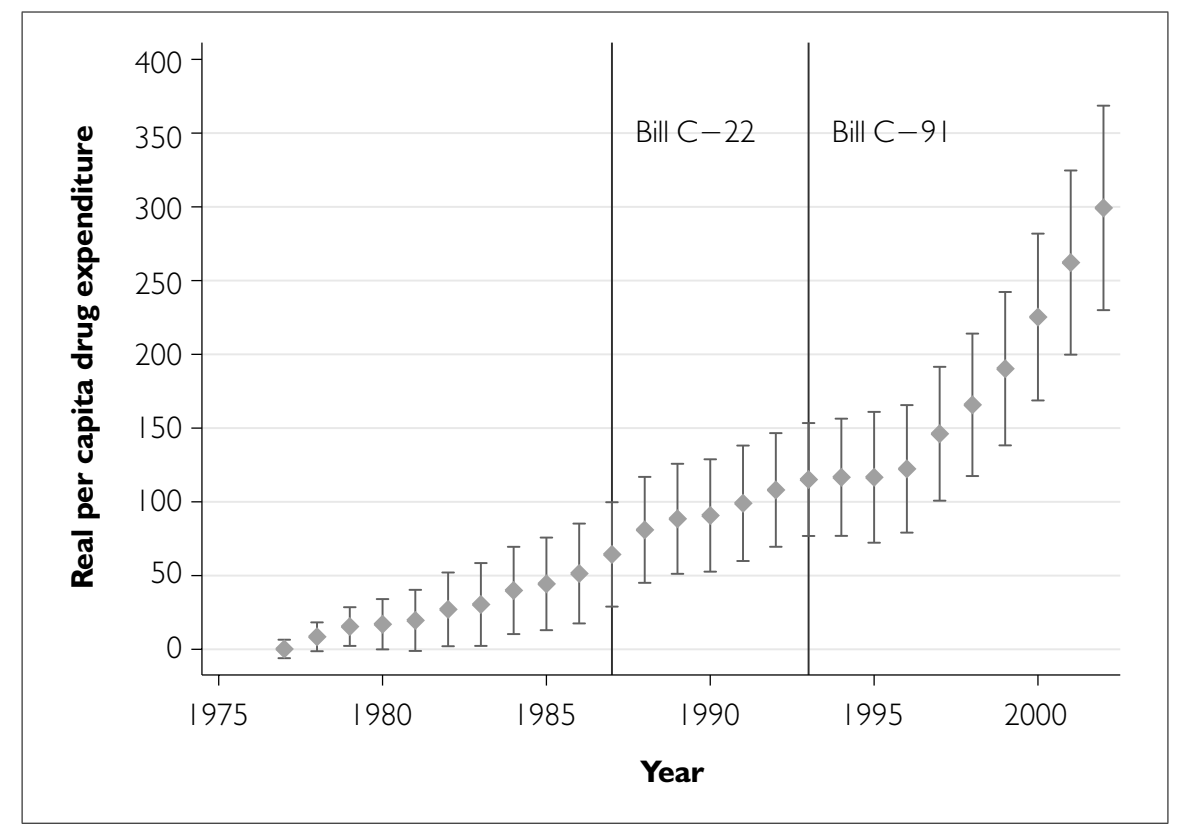

\section{Source of drug spending growth}

We next turned to comparative US data on both drug price inflation and nominal per capita drug expenditures to better inform the determinants of observed drug expenditure growth. Several observations emerge from inspection of rates of inflation of real drug prices in Canada and the United States (Figure 6). Viewing the top panel of Figure 6, which plots growth in real drug prices in Canada (all drugs, and patented drugs only), indicates no evidence of sustained drug price inflation after the extension of patent terms in 1987. As noted earlier, the price indices presented here are not sensitive to delays in generic drug market entry, so this finding is perhaps not surprising. The indices are sensitive, however, to the regulation of rates of growth of prices of exist- 
ing patented drugs by the PMPRB. The PMPRB mandates that patented drug price growth not exceed the three-year cumulative change in the CPI. Although this criterion has been satisfied, it is unclear whether PMPRB regulations are binding, as there is some evidence of a downward trend in all drug prices in Canada even before 1988.

The bottom panel of Figure 6 compares Canadian all-drugs real price inflation with that in the United States (where there is no federal price regulation). US drug price inflation has generally declined since 1986, suggesting that Canadian price declines are in part due to a North Americawide phenomenon, such as increasingly restrictive reimbursement policies instituted by drug insurers. On the other hand, the rates of drug price inflation have been consistently lower in Canada since 1987, suggesting that the PMPRB could have had some influence. Regardless of the reason, the lower rates of drug price inflation are consistent with the slowdown in the growth in real per capita prescription drug expenditures observed in the late 1980s. ${ }^{5}$

While the sharp increase in per capita drug costs observed after 1996 could have been due to delayed generic drug competition brought about by the extension of pat-

FIGURE 6. Year-over-year growth rates in real drug price indices 1982-2002, Canadian patented drugs, all Canadian drugs and all US drugs

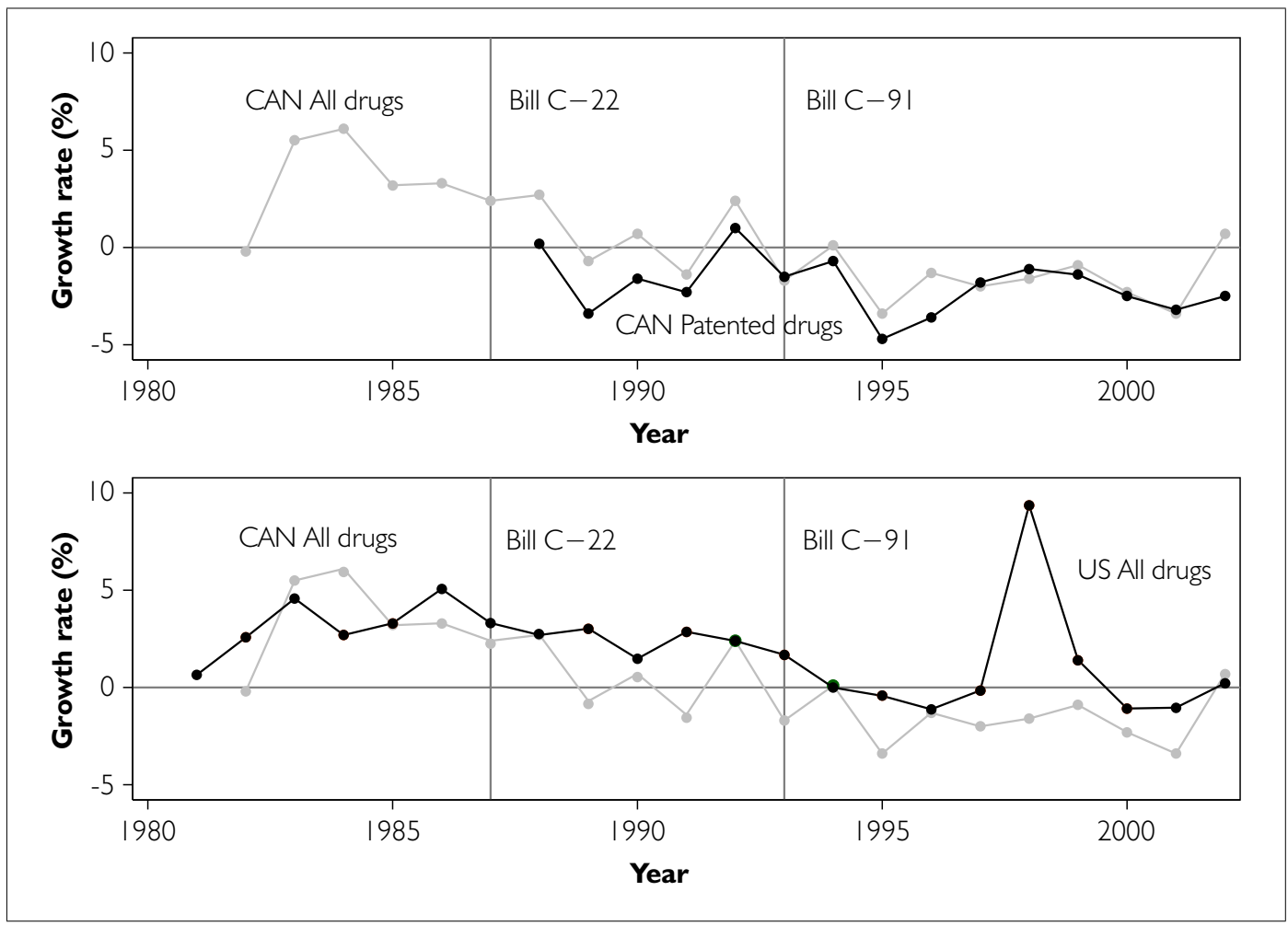

Note: All series measured as drug price inflation less inflation in the CPI. Beginning in 1999, the Canadian patented medicines price index (PMPI) reflects changes in the prices of patented drugs for human use only. 
ent terms, patent extension is perhaps not the sole reason. Inspection of Organisation for Economic Co-operation and Development (OECD) data on per capita nominal drug expenditures in Figure 7 indicates that the post-1996 expenditure growth has been even more pronounced in the United States than in Canada. This finding points to exogenous factors, such as the introduction of new drugs, as possible reasons. While it is possible that the patent changes were responsible for the entire increase in additional drug costs, it is highly unlikely; therefore, our estimate represents an upperbound estimate of the impact of patent extension on drug costs.

FIGURE 7. Nominal per capita prescription drug expenditures in the United States and Canada, 1975-2002

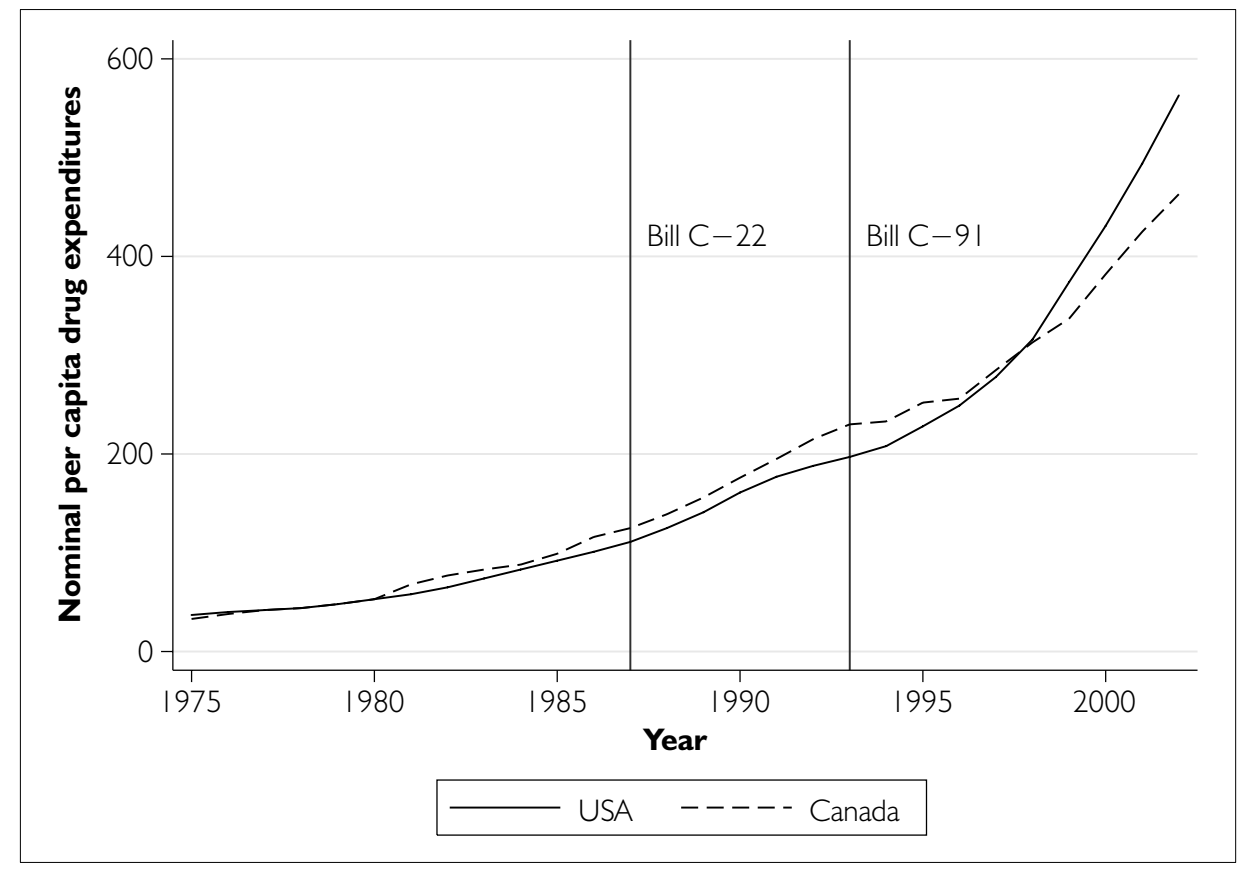

Source: Organisation for Economic Co-operation and Development (2004).

\section{Discussion and Policy Implications}

During the period 1969-1987, pharmaceutical drugs were not given patent protection, and Canada in effect gained a "free ride" on pharmaceutical innovation. In response to pressure applied by trading partners, and promises by patent-holding pharmaceutical firms to increase R\&D spending, over the period 1987-2001 Canada increased pharmaceutical patent term lengths to meet international standards. These increases in patent terms have been mitigated by federal drug price controls and 
increasingly restrictive reimbursement of pharmaceuticals by public prescription drug programs. Have these policy changes been good for Canada? This is a difficult question to answer fully. We provide some partial evidence on the benefits and costs of the policy changes in this study.

To assess benefits, we need to value the gains in health associated with the use of new drugs that were introduced, both domestically and abroad, because of these policy changes. It is difficult to quantify precisely the domestic value of the R\&D increase, but we attempt at least to estimate its order of magnitude (below).

This study provides strong evidence that the policy changes were associated with increased domestic $\mathrm{R} \& \mathrm{D}$ spending in the order of $\$ 4$ billion (1997 dollars). While we find that domestic R\&D has increased since 1987, it is unclear how much of the additional $R \& D$ expenditure represents an increase in global $R \& D$, as opposed to $R \& D$ that multinational firms shifted to Canada from elsewhere and would have occurred anyway. OECD data do suggest, however, that the worldwide rate of pharmaceutical R\&D grew at an increasing rate after 1987 (OECD 2002). This finding is consistent with the notion that the domestic policy changes increased global R\&D. ${ }^{6}$

One way to gauge indirectly the health impact of the patent term extension is to assess the number of innovative drugs - commonly referred to as "new molecular entities" or NMEs - that can be purchased for $\$ 4$ billion. Di Masi et al. (2003) estimate the average cost of bringing an NME to market to be US\$403 million in 2000 dollars; adding the forgone interest on funds tied up between the time of $R \& D$ investment and marketing raises the cost to US\$802 million. According to these estimates, the additional $\mathrm{R} \& \mathrm{D}$ spending in Canada could have supported the development of four to six NMEs.

Lichtenberg (2004) offers a way of quantifying the value of these additional NMEs. He provides a formula that converts NMEs into health outcomes, measured using life expectancy (LE) at birth. Using annual US time-series data on LE, health expenditure and NMEs introduced over the period 1960-2001, he estimates that every percentage increase in NMEs increases LE by $0.039 \%$. Evaluating this proportional response at his sample mean values of LE (73.1) and NME (21.1) implies that every NME increases LE by 0.135 years (1.62 months). Taking Lichtenberg's estimate at face value, and assuming that the four to six NMEs developed domestically are as productive, on average, as the NMEs in his data, we estimated that the $\$ 4$ billion domestic pharmaceutical R\&D increase has increased Canadians' LE by between 0.54 and 0.81 years. Topel and Murphy (2003) estimate that the average value of a life-year is approximately US\$150,000. Ignoring US-Canada exchange rates, the Topel and Murphy value of life-year estimates implies that the domestic pharmaceutical R\&D increase is worth between $\$ 81,000$ and $\$ 121,500$ per Canadian.

Some argue that pharmaceutical $R \& D$ is valuable for its impact on economic development: pharmaceutical jobs are "good jobs." We note that most pharmaceutical 
$\mathrm{R} \& \mathrm{D}$ takes the form of pre-marketing testing. Indeed, Canada has historically not been a centre for drug discovery; only three of the 1,061 NMEs introduced globally during the period 1975-1994 were discovered in Canada (PMPRB 1997). While such pharmaceutical sector jobs are indeed well paid, assessment of the economic development impact of pharmaceutical R\&D involves comparison of the value of the productivity of personnel in the pharmaceutical sector compared to what the value of their productivity would have been had they been instead deployed in some other sector. We are agnostic on this issue.

How much has been transferred to drug firms because of the policy? After controlling for real per capita GDP, prescriber density and other time-varying covariates, we find no marked increases in drug expenditure immediately after patent terms were extended in 1987. Indeed, per capita drug expenditures growth slowed in the early 1990s. Our results differ from those reported by Jones et al. (2001), who analyze prices paid for 82 different drugs by the British Columbia Pharmacare program over the period 1981-1994 and conclude that prices increased substantially in the post-patent period 1988-1994.

We do detect a sharp increase in drug expenditures after 1996. Assuming that this increase represents the effects of delayed competition from generic drugs, we estimate a profit increase over the period 1996-2002 of about $\$ 4$ billion (1997 dollars). This works out to $\$ 667$ million per year, or under $4 \%$ of the $\$ 18$ billion spent on prescription drugs annually (CIHI 2005a). This estimate represents an upper bound of the patent-induced drug cost increase, as costs likely have increased for other reasons. First, in an analysis of the sources of oral solid drug expenditure growth since 1998, Morgan (2004) finds no evidence of price inflation. Increases in drug use and substitution of new drugs for old drugs, on the other hand, were major drivers of drug costs. Second, since 1996, per capita drug expenditure has increased faster in the United States, where patent terms have not been extended, suggesting that other factors may indeed be at work. Third, we estimate that the elasticity of total retail prescription drug expenditure with respect to lagged public drug expenditure is 0.27 . This estimate implies that the retrenchment of public sector drug plans following the economic slowdown of the early 1990s has likely depressed pharmaceutical expenditure growth. Assessment of the role of price regulation by the PMPRB in constraining drug spending is less clear, given that real drug price inflation has been slowing in both Canada and the United States, even before the introduction of the PMPRB in 1988. On the other hand, rates of real drug price inflation have been consistently lower in Canada after 1988, suggesting that the PMPRB may have had some role. Taken together, these factors suggest that the combination of the federal patent term extension, coupled with federal price regulation and provincial drug plan cutbacks, has boosted the value of pharmaceutical R\&D by an amount greater than the amount transferred to patent holders.

What have been the economic costs of the policy? These take three forms: (1) the 
health gains not realized because of the reduction in drug consumption due to higher drug prices, discussed earlier; (2) the value of the reduction in consumption and work effort (i.e., the disincentive effects) associated with the additional taxation of consumption and labour levied in order to raise the public sector funds needed to cover additional drug spending ${ }^{7}$; and (3) the cost of "rent seeking" activities - the value of societal resources used for the purpose of securing and maintaining lengthened patent terms (this would include the costs of litigation surrounding the so-called NOC link regulations that were introduced as part of Bill C-91). On the first and second points, the drug use for the majority of the population appears to be relatively price insensitive, and post-patent drug price growth in Canada has been muted, suggesting that welfare losses may be modest. The magnitude of the third cost component remains an open question. We suspect, however, that it is much less than the value of the increase in $R \& D$, suggesting that the policy changes have been beneficial for Canada.

Correspondence may be directed to: Paul Grootendorst, Faculty of Pharmacy, University of Toronto, 144 College Street, Room 601, Toronto, ON M5S 3M2. Tel: 416-946-3994. E-mail: paul.grootendorst@utoronto.ca.

\section{ACKNOWLEDGMENTS}

The authors thank Dorothy Rhodes of IMS Health Canada; Kimberly Arscott, Geoff Ballinger, Ian Button and Marc Lalonde of the Canadian Institute for Health Information; Bert Plaus and Robert Schellings of Statistics Canada; Ron Corvari of the Patented Medicine Prices Review Board; Barry Power of the Canadian Pharmacists Association; and Neil Palmer of Palmer D'Angelo Consulting Inc. for providing data and assistance. Heather Bennett, Tom Brogan, Jillian Cohen, Susan Grant, Paul Jacobson, Jim Keon, Mitchell Levine, Irwin Lipnowski, Lonnie Magee, Steve Morgan, Ken Potvin, Gregg Szabo, Don Willison, Frank Windmeijer and participants at the 2004 Canadian Health Economics Study Group, the 2004 Canadian Association for Health Services and Policy Research conference, the 2002 Delta Marsh Conference on the Economics of Health Care Reform, and the Toronto Health Economics Network are thanked for helpful comments. Minsup Shim provided invaluable project support.

Grootendorst acknowledges support of the Premier's Research Excellence Award. Di Matteo acknowledges the financial support of the Social Sciences and Humanities Research Council of Canada. This study received financial support from the Father Sean O'Sullivan Research Centre, St. Joseph's Hospital, Hamilton, ON. All errors are the responsibility of the authors.

\section{NOTES}

1. A referee notes that the pressure to increase domestic drug patent terms was exerted out of concern that Canada's use of compulsory licensing would be emulated by large developing countries such as Brazil, China and India. Doern and Sharaput (2000) provide further insights into the political economy of intellectual property protection in Canada. 
2. After a generic drug firm has satisfied the conditions required to receive an NOC, under the terms of Bill C-91 it is required to serve a "Notice of Allegation" on the incumbent that the new product will not infringe any active patents. The incumbent then has 45 days to apply to the courts for an order prohibiting the issuance of an NOC. If such an application is filed, the regulator is automatically precluded from issuing an NOC until 24 months have elapsed, the court hearing, or until patent expiry, whichever occurs first (Hore 2000). According to the generic drug industry, this "NOC-linkage" legislation, combined with the industry practice of "evergreening" - listing additional patents on the colour, clinical indications or other features of the medication throughout the life of the initial patent (Anderson 1997) - has further extended effective patent terms and has led to a sharp increase in patent-related litigation. For perspectives by the associations of brand and generic drug firms, see, respectively, http://www.canadapharma. org/Industry_Publications/Information_Guide/section2_e.html and http://www.cdma-acfpp. org/en/news/dec_06_04.shtml. (Retrieved December 25, 2006.)

3. These programs apply to seniors, the indigent and other beneficiary groups, and collectively account for about $40 \%$ of total national retail prescription drug spending (CIHIa).

4. The square of GDP, per capita physicians, the hospital share of total health expenditures and age variables were included in the model to account for potential non-linearities between the covariates and drug costs. See Di Matteo (2003) for a discussion.

5. It should also be noted that the use of drug price indexes as a means of separating market exclusivity from drug price regulation may be problematic, given that the index does not capture the effect of price regulation on new drugs and the introduction of new drugs seems to be a significant factor after 1996.

6. This finding could also reflect the increase in foreign pharmaceutical R\&D due to the domestic policy changes. Alternatively, a referee notes that the global increase in pharmaceutical R\&D observed after 1987 could imply that domestic pharmaceutical R\&D would have increased even without the patent extension. While we cannot discount this possibility, we note that Pazderka (1999) finds the impact of the global R\&D expansion on domestic R\&D to be modest at best.

7. Dahlby (1994) has estimated that the welfare cost associated with the use of provincial income taxes to raise an additional dollar of public funds is about $\$ 0.66$. This means that the welfare gain from $\$ 1$ of public sector outlays needs to be $\$ 1.66$ just to be welfare-neutral.

\section{REFERENCES}

Anderson, M. 1997. "Evergreening in the Canadian Pharmaceutical Industry." Mimeo. Queen's University, Kingston, ON, Canada.

Anis, A.H. 2000. "Pharmaceutical Policies in Canada: Another Example of Federal-Provincial Discord." Canadian Medical Association Journal 162: 523-26.

Anis, A.H. and Q. Wen. 1998. "Price Regulation of Pharmaceuticals in Canada." Journal of Health Economics 17: 21-38.

Bae, J.P. 1997. "Research on Pharmaceutical Drug Development, Use, and Outcomes: Drug Patent Expirations and the Speed of Generic Entry." Health Services Research 32: 87-101.

Berndt, E.R. 2002."Pharmaceuticals in US Health Care: Determinants of Quantity and Price." Journal of Economic Perspectives 16: 45-66.

Berndt, E.R., D.M. Cutler, R.G. Frank, Z. Griliches, J.P. Newhouse and J.E. Triplett. 2000.

"Medical Care Prices and Output" (Chapter 3). In A.J. Cuyler and J.P. Newhouse, eds., Handbook 
The Effect of Pharmaceutical Patent Term Length on Research and

Development and Drug Expenditures in Canada

of Health Economics, vol. 1A. Amsterdam: Elsevier.

British Columbia Pharmacare Trends, 2000. Victoria, BC: Ministry of Health Services, 2001. Retrieved April 25, 2006.

Britton, J.N.H. 1998. "Is the Impact of the North American Trade Agreements Zero? The

Canadian Case." Canadian Journal of Regional Science 21(2): 167-96.

Canada. 1985. Report of the Commission of Inquiry on the Pharmaceutical Industry (The Eastman Commission Report). Ottawa: Supply and Services Canada.

Canadian Institute for Health Information (CIHI). 2005a. Drug Expenditure in Canada 19852004. Ottawa: Author.

Canadian Institute for Health Information (CIHI). 2005b. National Health Expenditure Trends, 1975-2004. Ottawa: Author.

Dahlby, B. 1994. “The Distortionary Effect of Rising Taxes." In W.R. Robson and W. Scarth, eds., Deficit Reduction: What Pain, What Gain? (pp. 44-72). Toronto: C.D. Howe Institute.

Dahlby, B. 2005. “A Framework for Evaluating Provincial R\&D Tax Subsidies." Canadian Public Policy 31(1): 45-58.

Danzon, P.M. 1997. Pharmaceutical Price Regulation: National Policies versus Global Interests. Washington, DC: American Enterprise Institute.

Di Masi, J.A., R.W. Hansen and H.R. Grabowski. 2003."The Price of Innovation: New Estimates of Drug Development Costs." Journal of Health Economics 22: 151-85.

Di Matteo, L. 2003. “The Income Elasticity of Health Care Spending." European Journal of Health Economics 4(1): 20-29.

Doern, G.B. and M. Sharaput. 2000. Canadian Intellectual Property: The Politics of Innovating Institutions and Interests. Toronto: University of Toronto Press.

Frank, R.G. and D.S. Salkever. 1992."Pricing, Patent Loss and the Market for Pharmaceuticals." Southern Economic Journal 59: 165-79.

Griliches, Z. and I. Cockburn. 1995. "Generics and New Goods in Pharmaceutical Price Indexes." American Economic Review 84: 1213-32.

Grootendorst, P. 2002."Beneficiary Cost Sharing under Canadian Provincial Prescription Drug Benefit Programs: History and Assessment." Canadian Journal of Clinical Pharmacology 9: 79-99.

Grootendorst, P., L. Dolovich, B. O’Brien, A. Holbrook and A. Levy. 2001. “The Impact of Reference Pricing of Nitrates on the Use and Costs of Anti-anginal Drugs." Canadian Medical Association Journal 165: 1011-19.

Hore, E., 2000. "A Comparison of United States and Canadian Laws As They Affect Generic Pharmaceutical Market Entry." Food and Drug Law Journal 55(3): 373-88. Retrieved December 25, 2006. <http://www.fdli.org/pubs/Journal\%20Online/jour_toc/vol55_3.html>.

Hudson, J., 2000. “Generic Take-up in the Pharmaceutical Market Following Patent Expiry: A Multi-country Study". International Review of Law and Economics 20: 205-21.

Industry Canada. 1997 (February). Review of the Patent Act Amendment Act, 1992 (Bill C-91). Ottawa: Author.

Iqbal, M. 1995."R\&D Tax Incentive Comparisons: Canadian and US Large Manufacturing Industries." Canadian Tax Journal 43: 120-31.

Jones, J.C.H., T. Potashnik and A. Zhang. 2001."Patents, Brand-Generic Competition and the 
Pricing of Ethical Drugs in Canada: Some Empirical Evidence from British Columbia, 19811994." Applied Economics 33: 947-56.

Lichtenberg, F.R. 2004. "Sources of US Longevity Increase, 1960-2001." Quarterly Review of Economics and Finance 44: 369-89.

Mackenzie, K.J. 2005. “Tax Subsidies for R\&D in Canadian Provinces." Canadian Public Policy 31(1): 29-44.

Mehanna, R.A. and H. Shamsub. 2002. "Who Is Benefiting the Most from NAFTA? An Intervention Time Series Analysis." Journal of Economic Development 27(2): 69-79.

Morgan, S. 2001. "Statistics and Drug Utilization: Are Prescribing Rates Really That High?” Canadian Medical Association Journal 165: 1507-8.

Morgan, S. 2004. “Drug Spending in Canada: Recent Trends and Causes." Medical Care 42(7): 635-42.

Newey, W. and K. West. 1987."A Simple, Positive Semi-definite, Heteroscedasticity and Autocorrelation Consistent Covariance Matrix." Econometrica 55: 703-8.

Newhouse, J.P. 1992. "Medical Care Costs: How Much Welfare Loss?" Journal of Economic Perspectives 6: 3-21.

Okunade, A.A. and V.N.R. Murthy. 2002."Technology As a 'Major Driver' of Health Care Costs: A Co-integration Analysis of the Newhouse Conjecture." Journal of Health Economics 21: 147-59.

Organisation for Economic Co-operation and Development (OECD). 2002. Research and Development Expenditure in Industry 1987-2000: 2002 Edition. Paris: Author.

Organisation for Economic Co-operation and Development (OECD). 2004. Health Data. Paris: Author.

Patented Medicine Prices Review Board (PMPRB). 1997. A Comparison of Pharmacentical Research and Development Spending. Study Series S-9709. Ottawa: Author.

Patented Medicine Prices Review Board (PMPRB). 2004. 2003 Annual Report. Ottawa: Author. Pazderka, B. 1999. "Patent Protection and Pharmaceutical R\&D Spending in Canada." Canadian Public Policy 25: 29-46.

Scott-Morton, F.M. 2000. "Barriers to Entry, Brand Advertising, and Generic Entry in the US Pharmaceutical Industry." International Journal of Industrial Organization 18: 1085-104.

Singh, P. 2002. "NAFTA and Labor: A Canadian Perspective." Journal of Labor Research 23(3): 433-46.

Stabile, M. 2001. "Private Insurance Subsidies and Public Health Care Markets: Evidence from Canada." Canadian Journal of Economics 34: 921-42.

Statistics Canada. 2003. Industrial Research and Development, 2003 Intentions. Catalogue no. 88202-XIB. Ottawa: Author.

Topel, R. and K. Murphy. 2003. “The Economic Value of Medical Research." In K.M. Murphy and R.H. Topel, eds., Measuring the Gains from Medical Research: An Economic Approach. Chicago: University of Chicago Press.

Tully, P. and E. Saint-Pierre. 1997. “Downsizing Canada's Hospitals, 1986/87 to 1994/95." Health Reports 8: 33-39.

Vandergrift, M. and P. Kanavos. 1997. "Health Policy versus Industrial Policy in the Pharmaceutical Sector: The Case of Canada." Health Policy 41: 241-60. 


\section{Appendix I: Data}

\section{Table A1. Data sources and description}

\begin{tabular}{|c|c|c|}
\hline DATA DESCRIPTION & DATA SOURCE & DETAILS \\
\hline $\begin{array}{l}\text { Retail pharmacy drug expendi- } \\
\text { tures data by province/region, } \\
\text { 1976-2002' }\end{array}$ & $\begin{array}{l}\text { IMS Health Canada } \\
\text { http://www.imshealthcanada.com/ }\end{array}$ & $\begin{array}{l}\text { Canadian Drug } \\
\text { Store and Hospital } \\
\text { Purchases Audit }\end{array}$ \\
\hline $\begin{array}{l}\text { Public sector prescription drug } \\
\text { expenditures by province, } \\
\text { 1975-2002 }\end{array}$ & $\begin{array}{l}\text { Canadian Institute for Health Information (CIHI) } \\
\text { http://secure.cihi.ca/cihiweb/splash.html }\end{array}$ & $\begin{array}{l}2005 \text { NHEX: } \\
\text { National Health } \\
\text { Expenditures } \\
\text { Database }^{2,3}\end{array}$ \\
\hline $\begin{array}{l}\text { Number of active prescrib- } \\
\text { ing physicians per province, } \\
\text { 1975-2002 }\end{array}$ & $\mathrm{ClHI}$ & $\begin{array}{l}\text { Southam Medical } \\
\text { Database }\end{array}$ \\
\hline $\begin{array}{l}\text { Hospital sector share of total } \\
\text { healthcare spending by prov- } \\
\text { ince, 1975-2002 }\end{array}$ & $\mathrm{ClHI}$ & $\begin{array}{l}2005 \text { NHEX: } \\
\text { National Health } \\
\text { Expenditures } \\
\text { Database }^{2,3}\end{array}$ \\
\hline $\begin{array}{l}\text { Gross domestic product by } \\
\text { province, } 1975-1980 \text { and } \\
\text { 1981-20025 }\end{array}$ & \multicolumn{2}{|c|}{$\begin{array}{l}\text { CANSIM II: NL: VI23650, V687I9I. PEI: VI23662, V687203. NS: } \\
\text { VI23674, V6872I5. NB: VI23686, V687227. QC: VI23698, V687239. } \\
\text { ON: VI237I0, V68725I. MB: VI23722, V687263. SK: VI23734, } \\
\text { V687275. AB: VI23746, V687287. BC: V508446, V687299. }\end{array}$} \\
\hline $\begin{array}{l}\text { Provincial population by age and } \\
\text { sex group, 1975-2002 }\end{array}$ & $\begin{array}{l}\text { Statistics Canada Canadian Socio-economic } \\
\text { Information Management System (CANSIM II) } \\
\text { http://cansim2.statcan.ca/ }\end{array}$ & Table 510001 \\
\hline $\begin{array}{l}\text { Patented medicine price index, } \\
\text { 1988-2002 }\end{array}$ & $\begin{array}{l}\text { Patented Medicine Prices Review Board } \\
\text { http://www.pmprb.com/CMFiles/ } \\
\text { ar2003e30LWY-1062004-5966.pdf }\end{array}$ & Annual Report 2003 \\
\hline $\begin{array}{l}\text { Pharmaceuticals component of } \\
\text { Industrial Product Price Index } \\
(1992=100)\end{array}$ & CANSIM II & Series VI576093 \\
\hline $\begin{array}{l}\text { All items, national Consumer } \\
\text { Price Index }(1992=100) \\
\text { Canada }\end{array}$ & CANSIM II & Series V735319 \\
\hline $\begin{array}{l}\text { Drugs \& Pharmaceuticals com- } \\
\text { ponent of Producer Price Index } \\
(1982=100)\end{array}$ & $\begin{array}{l}\text { US Bureau of Labor Statistics, Producer Price } \\
\text { Index - Commodities }\end{array}$ & Series WPU063 \\
\hline
\end{tabular}




\section{Table A1. Continued}

\begin{tabular}{|l|l|l|}
\hline DATA DESCRIPTION & DATA SOURCE & DETAILS \\
\hline $\begin{array}{l}\text { All items, national Consumer } \\
\text { Price Index (1982-84=100), } \\
\text { USA }\end{array}$ & CITIBASE (DRI Economic Database) & Series PUNEW \\
\hline $\begin{array}{l}\text { Nominal per capita drug } \\
\text { expenditures, Canada and USA, } \\
\text { 1972-2002 }\end{array}$ & OECD Health Data, 2004 & \\
\hline $\begin{array}{l}\text { Pharmaceutical R\&D expen- } \\
\text { ditures by patentees, Canada, } \\
\text { 1988-2002 }\end{array}$ & $\begin{array}{l}\text { Patented Medicine Prices Review Board } \\
\text { http://www.pmprb-cepmb.gc.ca/CMFiles/ } \\
\text { pmprb-ar04-eI 5MYB-682005-9338.pdf }\end{array}$ & Annual Report 2004 \\
\hline $\begin{array}{l}\text { Total R\&D expenditure, by } \\
\text { industrial sector, Canada, } \\
\text { 1972-20027 }\end{array}$ & $\begin{array}{l}\text { Statistics Canada Industrial Research and } \\
\text { Development } \\
\text { Catalogue no. 88-202-XIB }\end{array}$ & $\begin{array}{l}\text { Publication years: } \\
2003-1999,1997, \\
\text { 1995, 1993-1984 }\end{array}$ \\
\hline $\begin{array}{l}\text { Final domestic demand implicit } \\
\text { price index, Canada, 1972- } \\
2002\end{array}$ & CANSIM II & $\begin{array}{l}\text { V508250 } \\
(197 \text { I-1989) } \\
\text { V3840594 } \\
(1981-2002)\end{array}$ \\
\hline
\end{tabular}

\section{Notes:}

I. The IMS data on drug expenditures in Alberta in 1976 arrived combined with expenditures in the Prairie region (Saskatchewan and Manitoba). The 1976 value for Alberta alone was estimated by applying Alberta's average share of the total drug expenditure in Alberta and the Prairie region for the years 1977-1980 to the combined 1976 value. Although IMS provides separate data on in-hospital drug expenditures, these data were not used because their quality declined due to the reduction in sample size following the spate of hospital closures in Canada in the 1990s.

2. The NHEX data were taken from Canadian Institute for Health Information, Drug Expenditure in Canada: 1985-2004 (CIHI 2005a). Data on prescription drug expenditures from the period 1975-1984 were obtained from earlier issues of the same publication.

3. There are several differences between the IMS and $\mathrm{ClHI}$ prescription drug expenditures data that preclude a direct comparison of their levels. First, the IMS data include expenditures on both prescription drugs and non-prescription drugs that are not available outside a pharmacy. Although the set of "pharmacy only" non-prescription drugs varies by province, it typically includes items such as over-the-counter antihistamines, antifungal and acid-suppressing drugs and typically excludes items that are likely unaffected by the patent changes, such as oral hygiene products, vitamins and herbal remedies. Many of the provincial governments reimburse "pharmacy only" non-prescription drugs, but typically only a limited number of such drugs. Second, the IMS data are based on retail pharmacy sales and therefore exclude drug spending in longterm care (LTC) facilities. LTC drug expenditures are included in the CIHI data, however, because these expenditures are typically assumed by provincial governments. Nevertheless, the LTC share of total provincial government outpatient drug spending is small; for example, it accounted for only 5\% of British Columbia Pharmacare expenditure in fiscal 1999 (British Columbia 200 I). Third, the IMS data exclude dispensing fees, whereas the $\mathrm{ClHI}$ data include them.

4. The following physician specialties likely prescribe to outpatients and were included: family medicine, internal medicine, dermatology, neurology, paediatrics, physical medicine, psychiatry, emergency medicine, medical microbiology, general surgery, cardio and thoracic surgery, neurosurgery, obstetrics-gynecology, ophthalmology, otolaryngology, orthopaedic surgery, plastic surgery and urology.

5. CANSIM provides separate provincial GDP series over the periods I96 I-96 and I98I-2000. The province-specific CANSIM labels for these two series are reported. These two series were combined to form one continuous series over the sample period 1976-2000, as follows: We multiplied the GDP data over the five-year period 1976-80 from the first series by an adjustment factor to make them comparable to the second series. The adjustment factor was the mean province-specific ratio of the second to the first series for each year over the "overlapping" period 1981-85. GDP and all other expenditure series were deflated using Statistic Canada's final domestic demand implicit price index $(1997=100)$.

6. PMPRB reports on R\&D expenditure of firms that sold patented medicines in the reporting year. Data are available for the period 19882002. Statistics Canada reports on the R\&D expenditure of all firms, irrespective of their patentee status. These data are available since 1972.

7. Data on annual total R\&D-to-sales ratios reported in Figure I are not directly provided by Statistics Canada. Data on current R\&D-to-sales ratio (where current $=$ total - capital) were provided. To construct the series, we first recovered annual sales in each sector by dividing current R\&D expenditures by current R\&D-to-sales ratios (both of these are reported), and then divided total R\&D by their respective sales revenues.

8. We received from Statistics Canada a special tabulation of the most recently revised R\&D expenditure data as of November 2003. Some of these data may differ from the published figure. 


\section{Appendix II: Regression Equations \& Estimation Procedure}

The estimating equation for the drug expenditures model is as follows:

$$
\operatorname{Tot}_{\operatorname{Drug}}{ }_{\mathrm{it}}=\alpha_{\mathrm{i}}+\beta_{\mathrm{t}}+\gamma \operatorname{PubDrug}_{\mathrm{it}-1}+\delta^{\mathrm{T}} Z_{\mathrm{it}}+\varepsilon_{\mathrm{it}}
$$

where TotDrug ${ }_{i t}$ refers to real per capita retail prescription drug expenditures in province/region $i$ and year $t$. Drug expenditures were deflated with a GDP deflator; our measure of "real" drug expenditures will therefore increase as pharmaceutical price inflation exceeds economywide inflation. The $\alpha_{\mathrm{i}}$ and $\beta_{\mathrm{t}}$ are province/region and year effects, respectively. PubDrug ${ }_{i t-1}$ denotes real per capita public drug expenditures in region $i$ at year $t-1$, and the parameter $\gamma$ denotes its impact on TotDrug ${ }_{\text {it }}$, where we expect $0<\gamma<1 . Z_{\text {it }}$ is the vector of variables included to reduce confounding, including real per capita GDP and other variables described in the text, and $\delta$ is a conformable vector of unknown parameters. $\varepsilon_{\mathrm{it}}$ is the error term.

To identify the effect of the post-Bill C-22 patent changes using the Statistics Canada pharmaceutical R\&D expenditure data, we initially assumed that the pre-Bill $\mathrm{C}-22$ linear trend would have continued had the patent terms not been changed. The estimating model is

$$
R E D_{\mathrm{t}}=\theta_{0}+\theta_{1} \mathrm{C} 22_{\mathrm{t}}+\theta_{2} t+\theta_{3} \mathrm{C} 22_{\mathrm{t}} \times t+v_{\mathrm{t}}
$$

where $R E D_{\mathrm{t}}$ refers to total nominal pharmaceutical $\mathrm{R} \& \mathrm{D}$ expenditures in year $t$ (1972-2002). The C22 indicator is designed to capture the effects of all patent policy changes after December 1987, the period following the introduction of Bill C-22; it is equal to 0 for $1972-86,1 / 12$ for 1987 and 1 for $1988-2002$. The $\theta_{j}, j=0,1,2,3$, are unknown parameters, and $v_{\text {it }}$ is the error term. The real increase in $R E D$ in year $t$ $>1987$ is $\left(\theta_{1}+\theta_{3} t\right) \times 100 /$ def $_{\mathfrak{t}^{\prime}}$ where def $f_{\mathrm{t}}$ is the value of the GDP deflator in year $t$ with $1997=100$.

We then relaxed the assumption that all post-1987 pharmaceutical R\&D growth was due to patent changes. To do so, we used the "difference-in-differences" approach: We subtracted from the pre-post 1987 change in pharmaceutical R\&D the component that would have occurred even without the patent changes. This latter component was proxied by the pre-post 1987 change in motor vehicle sector R\&D. The $p$-value associated with the $t$-test for the equality of the slopes of the linear trend in $\mathrm{R} \& \mathrm{D}$ expenditure in the two sectors prior to Bill C-22 was $p=0.803$; the $p$-value for the test of equality of intercepts was $p=0.806$. The estimating equation for the difference-in-differences model is: 


$$
\begin{aligned}
& R E D_{\text {it }}=\phi_{0}+\phi_{1} \text { pharm }_{\mathrm{i}}+\phi_{2} \mathrm{C} 22_{\mathrm{t}}+\phi_{3} t+\phi_{4} \text { pharm }_{\mathrm{i}} \times t \\
& +\phi_{5} \mathrm{C}_{2} \times t+\phi_{6} \text { pharm }_{\mathrm{i}} \times \mathrm{C} 22_{\mathrm{t}}+\phi_{7} \text { pharm }_{\mathrm{i}} \times \mathrm{C} 22_{\mathrm{t}} \times t+\omega_{\mathrm{it}}
\end{aligned}
$$

where $R E D_{\text {it }}$ refers to the total nominal R\&D expenditures in sector $i$ (pharmaceutical or motor vehicles) and year $t(1972-2002)$. The variable pharm $\mathrm{i}_{\mathrm{i}}$ is an indicator of the pharmaceutical sector, $\mathrm{C} 22_{\mathrm{t}}$ is defined as before and $\omega_{\mathrm{it}}$ is the error term. The $\phi_{\mathrm{j}}$, $j=0,1, \ldots, 7$, are unknown parameters. The real post-Bill C-22 increase in $R E D$ for the pharmaceutical sector in year $t>1987$ is $\left(\phi_{6}+\phi_{7} t\right) \times 100 /$ def $_{\mathrm{t}^{*}}$ 